reading this collection of literary essays I am not sure about the answer. I am sure about one thing though: we have to ask these questions more often. The essays are good craftwork - apart from some printing and grammati$\mathrm{cal} /$ syntactic mistakes; however, many of them left me wanting a deeper insight or a more compelling problemproposal, Ambiguity offers an endless range of opportunities for interpretation but as noted by the authors of the collection themselves, the investigation of ambiguity might be an endless task (talk?), which also means that the topic might be quite vague for an essay, and, especially, for a whole collection of essays. Pokrivčák is anxious to see cultural studies taking over literary studies, and he brings up "usefulness" as one of the main arguments of those who push cultural studies to the front. Although I definitely disagree with the notion of literature having to serve some purpose, I do think that literary studies have to have some effectiveness. According to Pokrivčák, among many possible answers to the question "what does literature communicate?" "in a post-relativistic and, hopefully, post-ideological literary criticism, the natural ones may be those which would re-connect the meaning of literary work to human universals." More particularly, such an answer can be found in Dickinson's poetry - "the sense of pleasure and beauty, which is also the sense of truth and knowledge, the enrichment of our being" (223).
The final essay of this book presents the rhetorical use of the ambiguous, in President Barack Obama's speech as an example of a great contemporary rhetorician. Ann Dobyns analyzes how Obama uses the ambiguous in his speech on racial issues as a tool to unpack and negotiate differences and understand their complexity, and then eventually trigger ethical judgement as well as action in his audience. I think this is a perfect ending to this collection: at the end of the day, after a literary journey, ambiguity must come down to a better or worse, hopefully ethical "judgement about how to live in the world together" (241).

\section{Zsuzsanna Czifra}

\section{Fantastic Liminality}

Sándor Klapcsik, Liminality in Fantastic Fiction (Jefferson, NC and London: McFarland, 2012)

There is an abundance of essays, studies and books on science fiction, fantasy and detective novels. The poststructuralist approach applied to analyze contemporary cultural phenomena, especially literature, is one of the favorites used to gain insight into the workings and mechanisms of present-day works of art, as well. Agatha Christie, Stanislav Lem, Neil Gaiman and Philip K. Dick are also among those popular writers whose works have been extensively interpreted and theorized about. Sándor Klapcsik’s 
Liminality in Fantastic Fiction is breaking new ground when it synthesizes the three areas and scrutinizes the versatile works of these four authors from the perspective of liminality. The book "intends to serve as an introduction to liminality in postmodern culture and fantastic fiction" (5), but it achieves more: the enterprise of investigating liminality from the point of view of poststructuralism ventures into the depth of studying liminality and examining what kind of liminal positions open up in fantastic fiction (detective fiction, fantasy, and a selection of different subgenres of science fiction, for example cyberpunk or alternative histories).

Liminality is the axis around which the four chapters of the book rotate. Agatha Christie's detective stories are dissected from the point of view of certain spatial and thematic forms of liminality that might appear covert at first sight. The chapter demonstrates that the detective is a liminal figure, who represents a constantly fluctuating movement between the margins and the center of the society, since cultural traditions and hierarchical binaries of social structures are of ambivalent nature. This ambivalence is enhanced by the rationality of the detective story, since the figure of the detective is the representative of Enlightenment rationalism, therefore any criminal case is a puzzle to be solved so that the original, pristine order of the world could be restored. Nevertheless, according to Klapcsik, Agatha Christie's detective fiction hovers around both this rationality and the irrationality of thematic and narrative deviations. Fantastic (Gothic) elements appear in The Thirteen Problems, "A Christmas Tragedy," "The Bloodstained Pavement" or "The Idol House Astarte." In those novels where the head of the family is murdered (Crooked House, Ordeal by Innocence), the transitional period is informed by a Bakhtinian carnivalesque, and the emergent, new social order is dependent on the detective's successful investigation. The argument successfully proves that Christie's detective fiction, similar to other detective stories, corresponds to Victor Turner's oft-quoted theory on the temporary and re-constitutive characteristics of liminality. The liminal chaos of cultural, social and hierarchical positions is reinstated by actions taking place in liminal periods (the duration of the investigation) and usually in liminal spaces such as trains (Murder on the Orient Express or 4.50 from Paddington). In addition, Christie's detective novel is characterized by an abstract chronotope: the texts hinge on a neverchanging, abstract space-time structure, since neither Miss Marple nor Poirot change in character throughout the span of Christie's published stories. The liminality of narration is made apparent in narrative transgressions or "narrative games," misleading focalization, and metafiction. Klapcsik aptly argues that Christie's or her fictional writer-ego's self-reflexive presence in the text (The Body in the Library or The Murder of 
Roger Ackroyd) subvert the traditional thematic and narrative boundaries of detective fiction.

If the first chapter explores how conventional detective stories might resonate with fantastic themes of such genres as horror, fantasy and science fiction, the second chapter of the book examines Neil Gaiman's fiction mainly from the vantage points of generic, narrative and thematic liminality. Gaiman's texts are heavily laden with intertextual allusions and stylistic bricolage, therefore they provide an excellent ground for the argument to find evidence of how Gaiman's writings transgress generic, narrative and thematic boundaries and how they oscillate between various genres. In order to analyze these transgressions, the argument leans on the fantasy concepts of J.R.R. Tolkien and Tzvetan Todorov, among others. As the chapter finds these fantasy theories inadequate to describe the liminality in Gaiman's fiction, it turns to Linda Hutcheon's reading of irony and parody, Mieke Bal's studies of vision and Wolfgang Iser's reader response criticism. The analysis mainly focuses on Gaiman's short stories. Anansi Boys, Neverwhere and The Graveyard Book exemplify that plural narrative perspectives result in subjectivized narratives and estranged fantasy, liminal fantasy, where "the fantastic is no longer interpreted as a realm different and distant from consensus reality" (57). "Murder Mysteries," on the other hand, divert from the conventions of Farah Mendlesohn's concept of portal-quest fantasy and the embedded narration technique characterizing Club stories, as the narrative crosses the ontological boundaries between the two different levels of narration. Therefore the argument maintains and underlines Brian McHale's frequently referenced notion of the ontological aspect of postmodern fiction. Klapcsik elucidates the consistent intertextuality in Gaiman's stories with Genette's - rather outdated - version of hypertextuality and draws the conclusion that the dependence of texts on one another is primarily based on imitation in the texts. This issue of imitation is justly raised - for example "Shoggoth's Old Peculiar" is a "pseudo-Lovecraftian text" that revisits Lovecraftian themes and style - but simulation, which would be a much more sufficient theory (regardless of whether it is based on Deleuze's or Baudrillard's version) is not put into motion here. In contrast to this, Iser's idea of the textual gaps filled in by the reader and Paul deMan's concept of selfreflexive irony (permanent parabasis) are outstandingly well used in showing that Gaiman's liminal fantasy "lays bare its own fictionalizing process and subverts its fictional, fantastic world" (58).

The third chapter proposes that Stanislav Lem's fiction is a medley of science fiction and detective fiction elements, where the epistemological puzzles, among other things, provide a basis for the ontological aspects: Lem's novels subvert the limits of both science and science fiction, therefore they (especially 
Solaris) need to be labeled as metascience and meta-science-fiction, respectively. The argument also concentrates on a Lacanian version of mirroring, as the mirrored subject in the alien planets is reflected with "a difference, refraction, oscillation, a rupturing surprise" that is termed the revenge of the mirror. The logic of the chapter, similar to the other chapters of the book, follows a well-defined deconstructive trait informed by deMan's (Allegories of Reading) and Nietzsche's (Human, All Too Human) concepts of the reversal of cause and effect, where the cause is the result of the reconstruction of what happened after the event had an effect on the environment: this argument is used to illustrate how Lem's fiction drifts towards a liminal space between detective fiction and science fiction. In the technologized environment, the detectives, Pirx or Ijon Tichy investigate cases involving malfunctioning robots, hiding aliens or androids. Although the chapter focuses on "the inability to judge whether one encounters the real or a simulated image, original or replica, Self and the Other" (118) most of the cuttingedge postmodern theories (mask-theory, simulation, virtuality, avatars) remain more or less inarticulated. The metaphoric nature of language, on the other hand, is expressed and assessed to a great extent, and it is convincingly argued that Lem's works often selfreflexively parody (or mirror) themselves and the genre, therefore these stories might be taken to be satirical science fiction parodies or self-parodies. As the chapter is founded on the argument that Lem's works are the result of a linguistically conscious and selfreflexive effort, the question is raised whether the close-reading of these texts is hindered by the fact that Klapcsik reads them in translation.

The first three chapters designate a line leading to the probably best formulated and articulated fourth chapter on the interpretation of Philip K. Dick's stories from the point of view of "urbanity, liminality, multiplicity” (121). After an impressive introduction into paraspace, cyberspace and spatial hybridity based on the notions of Homi Bhabha, Scott Bukatman and Elizabeth Grosz, the liminal spatiality of some of Dick's novels is examined on the basis of the difference and oscillation between modernist planning and postmodernist play in urban architectural spaces. The book argues that the clear-cut modernist boundaries and pre-negotiated spaces based on centrality are replaced by decentered, constantly changing, asymmetrical and unmappable space. "Postmodernism is constituted in cyberspace," a quote from Paul Smethurst - via many other influential critics, for example Marshall McLuhan's, Charles Jencks's and the obligatory notions of Frederic Jameson - introduces virtuality by which the chapter argues that some of Dick's stories ("The Commuter," Ubik, Do Androids Dream of Electric Sheep?, “The Minority Report”) are set in such places/spaces, in which 
the conventional, modernist ways of moving around (corporeal journey) are coupled with the postmodern, digital space of speedy flows, flux, the oscillation of commutation. The subchapter on "cyberworlds and simulacra" studies the liminal and plural nature of cyber- and paraspaces of A Maze of Death, Ubik, "I Hope I Shall Arrive Soon," or The Three Stigmata of Palmer Eldritch. Although the argument seems to mingle different notions of simulation, it manages to reveal how Dick's multiple worlds resemble and anticipate the contemporary cyberspace of digital networks based on simulacra.

In sum, Liminality in Fantastic Fiction is a well-written, thoughtful and focused book rich in interpretations and close readings of canonic texts written by the probably most important authors of the genre. Nevertheless, the advantages of concentrating on the notion of liminality in fantastic fiction from a poststructuralist point of view have their own drawbacks. Liminality is a term that has too many definitions; the concept have been assessed from countless different points of view, and as the "Preface" and the "Introduction" demonstrate, the term itself has become a liminal, transgressive, bordercrossing, in-between, elusive concept that is very hard to put into motion and use for specific reading purposes.

Gyuris Norbert 